\title{
Cryogenic carbonates and cryogenic speleothem damage in the Za Hájovnou Cave (Javoříčko Karst, Czech Republic)
}

\author{
Karel ŽÁK ${ }^{1, *}$, Vladimír LIPTÁK ${ }^{2}$, Michal FILIPPI ${ }^{1}$, Monika ORVOŠOVÁ \\ Helena HERCMAN ${ }^{4}$ and Šárka MATOUŠKOVÁ ${ }^{1}$ \\ 1 The Czech Academy of Sciences, Institute of Geology, Rozvojová 269, 16500 Praha 6 - Lysolaje, Czech Republic \\ 2 Czech Speleological Society, Club 7-03 Javoříčko, Czech Republic \\ 3 Slovak Museum of Nature Protection and Speleology, Školská 4, 03101 Liptovský Mikuláš, Slovakia \\ 4 Institute of Geological Sciences, Polish Academy of Sciences, Twarda 51/55, 00-818 Warszawa, Poland
}

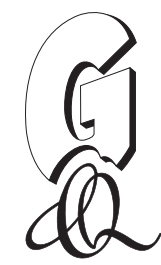

Žák, K., Lipták, V., Filippi, M., Orvošová, M., Hercman, H., Matoušková, Š., 2018. Cryogenic carbonates and cryogenic speleothem damage in the Za Hájovnou Cave (Javořičko Karst, Czech Republic). Geological Quarterly, 62 (4): 829-839, doi: $10.7306 / g q .1441$

Associate editor: Tadeusz M. Peryt

A new locality of coarse-grained cryogenic cave carbonates has been found in the Za Hájovnou Cave in Javořičko Karst in Central Moravia, Czech Republic. Crystals and crystal aggregates, usually up to $15 \mathrm{~mm}$ in size, form typical loose accumulations on the surface of large fallen limestone blocks and clays covering the bottoms of several cave chambers distant from the cave entrance. The cryogenic origin of the carbonates is supported by their mode of occurrence, specific crystal and aggregate morphology, and C and O stable isotope data. U-series dating of one sample of cryogenic carbonate (age $29.5 \pm 0.1$ ka) indicated that a period of karst water freezing occurred in marine isotope stage (MIS) 3 , within the Weichselian. The cave also hosts numerous examples of speleothem damage. As shown in this paper, some of these are clearly connected with freezing conditions and cave ice action.

Key words: cryogenic cave carbonates, speleothem damage, Javořičč Karst, U-series dating.

\section{INTRODUCTION}

Cryogenic cave carbonates (CCC) represent a rare type of secondary mineral formation (speleothem) in caves. They form by crystallization of the dissolved load of karst waters upon freezing in caves. Depending on the thickness of the layer of freezing water and thus also on the freezing rate, two main groups of CCC have been recognized (Žák et al., 2008). Fine-grained types $\left(\mathrm{CCC}_{\text {fine }}\right.$; abbreviations after Luetscher et al., 2013) form during rapid freezing of a thin layer of water, usually on the surface of ice in caves with high airflow or in cave entrance sections. These had already been recognized in the 1930s (Kunský, 1939). Coarse-grained types (CCC during slow freezing within larger water reservoirs. Details on the mechanism of formation of $\mathrm{CCC}_{\text {coarse }}$ have been elucidated by Žák et al. $(2004,2012)$ and Richter and Riechelmann (2008). The cryogenic origin of $\mathrm{CCC}_{\text {coarse }}$ was recently confirmed by the documentation of typical $\mathrm{CCC}_{\text {coarse }}$ accumulation directly within

\footnotetext{
* Corresponding author, e-mail: zak@gli.cas.cz

Received: February 8, 2018; accepted: June 7, 2018; first published online: December 10, 2018.
}

cave ice in a high-elevation cave in the Julian Alps (Colucci et al., 2017). Both groups of CCC differ from common speleothems in many aspects including the mode of occurrence (accumulations of loose particles, covering only a part of the cave floor surface, with locations independent of the cave drip sites or present-day water pools), morphology of the crystals and crystal aggregates, and $\mathrm{C}$ and $\mathrm{O}$ stable isotope data (Žák et al., 2018).

Here we focus only on $\mathrm{CCC}_{\text {coarse, }}$ which is the speleothem type discovered in the Za Hájovnou Cave. Generally, the following morphological types (groups) of $\mathrm{CCC}_{\text {coarse }}$ can be roughly distinguished:

- single crystals and their random or organized intergrowths/aggregates,

- fine- to coarse-crystalline, more or less (hemi-)spherical forms, and

- planar raft-like aggregates (Žák et al., 2018).

In the $\delta^{13} \mathrm{C}$ vs. $\delta^{18} \mathrm{O}$ plot, $\mathrm{C}$ and $\mathrm{O}$ stable isotope data of $\mathrm{CCC}_{\text {coarse }}$ from each locality follow a negatively sloped trend (increasing $\delta^{13} \mathrm{C}$ accompanied by strongly decreasing $\delta^{18} \mathrm{O}$, down to very low $\delta^{18} \mathrm{O}$ values <-20\% V-PDB; Žák et al., 2004; Richter and Riechelmann, 2008). A combination of the above-mentioned features enables an unequivocal identification of 
$\mathrm{CCC}_{\text {coarse }}$ and distinguishes them from other types of speleothem.

A great majority of the known $\mathrm{CCC}_{\text {coarse }}$ occurrences in Europe are located in low-altitude caves and are of pre-Holocene age (Žák et al., 2012). Within the caves, the position of the $\mathrm{CCC}_{\text {coarse }}$ sites is usually in large cave spaces, typically in cave sections which are not cooled to freezing temperatures by airflow today. In many of the sites documented in Central Europe, these cavities were separated from the outside atmosphere by cave sections completely filled with clastic deposits, and were only later made accessible by human activity (digging, quarrying, etc.). These Central European regions do not have permafrost conditions today, and the caves hosting $\mathrm{CCC}_{\text {coarse }}$ do not allow accumulation of freezing air, i.e., they do not have cave morphologies and entrance dimensions typical of ice caves existing in non-permafrost regions (cf. Perşoiu, 2018a). Under such conditions the only process which can cool down the cavities to freezing temperatures is the existence of permafrost in the past. Dated occurrences of $\mathrm{CCC}_{\text {coarse }}$ in caves of Central Europe have been used to estimate the minimum thickness of Weichselian permafrost (Žák et al., 2012). More rarely, $\mathrm{CCC}_{\text {coarse }}$ sites in caves where airflow cooling was possible are located at high elevations and are of Holocene age (Luetscher et al., 2013; Spötl and Cheng, 2014; Colucci et al., 2017).

The published model of CCC $_{\text {coarse }}$ formation (Žák et al., 2004, 2012; Richter and Riechelmann, 2008) supposes its precipitation within zones of relic permafrost at depth, especially during periods when the regional climate is ameliorating. This is explicable by the fact that permafrost aggradation and destruction displays a delay with respect to surface climatic changes (Pielsticker, 2000). During the most severe glacial conditions (stadials), the permafrost thickness increased and any deeper water infiltration would be restricted by the frozen zone. Underground cavities would remain filled with cave atmosphere (i.e., free of ice or water pools because of limited infiltration through the permafrost), but cooled to subfreezing temperatures within the permafrost. In contrast, during periods of climate warming (interstadials, transitions from glacials to interglacials), the amount of meteoric precipitation increased. Water infiltration also increased, being accompanied by permafrost destruction (thawing). When water percolated into a cavity in relic permafrost at depth, it formed water pools there, which froze slowly (Pielsticker, 2000). Published interpretations consider such environments within the permafrost undergoing melting from above to be the most suitable for the formation of $\mathrm{CCC}_{\text {coarse }}$ (the complete literature was reviewed in Žák et al., 2018). Most of the dated Central European sites formed during MIS 3, MIS 2 and during the transition to the Holocene. A precise correlation with Dansgaard-Oeschger events or other rapid climate oscillations (cf. Van Meerbeeck et al., 2009) is complicated by the delayed response of the permafrost zone with respect to climatic changes at the surface. Direct use of $\mathrm{CCC}_{\text {coarse }}$ as a palaeoclimatic indicator is therefore restricted. Nevertheless, it can be used as an indicator of former permafrost thickness (Žák et al., 2012).

In Central Europe, multiple finds of $\mathrm{CCC}_{\text {coarse }}$ which formed during the Weichselian have been reported from Germany, the western part of the Czech Republic, Slovakia and Poland. Only one cave with $\mathrm{CCC}_{\text {coarse }}$ occurrence has been described so far from the eastern part of the Czech Republic (Moravia). This find has been reported from the Javoríčko Cave located in the Javoříčko Karst, and U-series dated at $34.60 \pm 0.41$ to 38.09 \pm 0.60 ka (3 samples; Žák et al., 2012). Here we report another occurrence of $\mathrm{CCC}_{\text {coarse }}$ in the Za Hájovnou Cave, also located in the Javoŕícko Karst. The distance between the entrances of the two caves is only $~ 500 \mathrm{~m}$, and the find is therefore not surprising. Both caves also bear numerous examples of extensive speleothem damage, which has been interpreted to be mainly a result of former tectonic (and related seismic) activity by Bábek et al. (2015).

The purpose of this short communication is to introduce a new $\mathrm{CCC}_{\text {coarse }}$ locality in the $\mathrm{Za}$ Hájovnou Cave, to provide a bulk-sample U-series age of one of the richest $\mathrm{CCC}_{\text {coarse }}$ sites and to discuss ice-related processes as one of the important causes of abundant speleothem damage in this cave. It should be noted that this initial $\mathrm{CCC}_{\text {coarse }}$ study was carried only to demonstrate freezing conditions within the deep part of this cave during the Weichselian, without the aim of making a detailed study of climatic evolution of the cave or of extending the existing general model of $\mathrm{CCC}_{\text {coarse }}$ formation.

\section{ZA HÁJOVNOU CAVE, FIELD OBSERVATIONS AND SAMPLING}

The entrance to the Za Hájovnou Cave (Fig. 1) is located on a valley slope, $20 \mathrm{~m}$ above and to the north of the Javoríčka Creek (WGS 84 coordinates of the cave entrance $49.67431^{\circ} \mathrm{N}$, $16.91655^{\circ} \mathrm{E}, 388 \mathrm{~m}$ a.s.I.). The main entrance to the more famous Javoŕíčko Cave, developed as a show cave, is located slightly higher (at $\sim 445 \mathrm{~m}$ a.s.l.) on the opposite side of the valley (south of the creek).

The latest speleological discoveries in the Za Hájovnou Cave were provided by Vaněk (2012) and Vaněk and Kučera (2018). The former speleological history and description of the cave deposits in the near-entrance, sediment-filled corridors were reviewed by Musil (2005) and Kadlec et al. (2005). Abundant finds of vertebrate bones in this entrance cave section (mainly bears identified as $U$. deningeri) were dated by Lundberg et al. (2014).

The geology and speleogenesis of the area were summarized especially by Lundberg et al. (2014) and Bábek et al. (2015), and some basic information is provided also here. The Za Hájovnou Cave is hosted by Devonian limestone. The cave has a complex speleogenesis and sedimentary history involving several stages of the formation of cave spaces, and several stages of sedimentation in these spaces, starting most probably before the Quaternary. Almost complete filling of the entrance corridors occurred during several intervals in the Middle Pleistocene, covering a long interval between Marine Isotope Stage (MIS) 11 and MIS 5 (Lundberg et al., 2014). Fluvial deposits in the lower part of the entrance corridors are older than the Brunhes/Matuyama palaeomagnetic boundary (Kadlec et al., 2005). Since the evolution of the cave as a whole is not the subject of this study, we focus on its youngest history during the younger half of the Weichselian, i.e., on the presence of permafrost and on reasons for the speleothem damage. As suggested by the field situation, the cave was already fossil in this period (since at least MIS 5), with no fluvial processes and no open entrances. The present-day temperature in the cave is practically stable throughout the year (between 8 and $9^{\circ} \mathrm{C}$, with seasonal oscillations within $\sim 1^{\circ} \mathrm{C}$ ).

The general morphology of the cave, the lowest cavities of which reach $50 \mathrm{~m}$ below the surface of a south-oriented slope, is shown in Figure 1. Loose accumulations of $\mathrm{CCC}_{\text {coarse }}$ (Fig. 2), covering up to several square metres and forming layers up to 3 $\mathrm{cm}$ thick, have been recorded in the cave by cavers (V. Lipták and co-workers, 2014), who recognized their probable cryogenic origin. They occur mainly in the Katedrála (Cathedral), Sut'ový (Debris), Koridor (Corridor) and Ledový (Ice-like) cave chambers. 


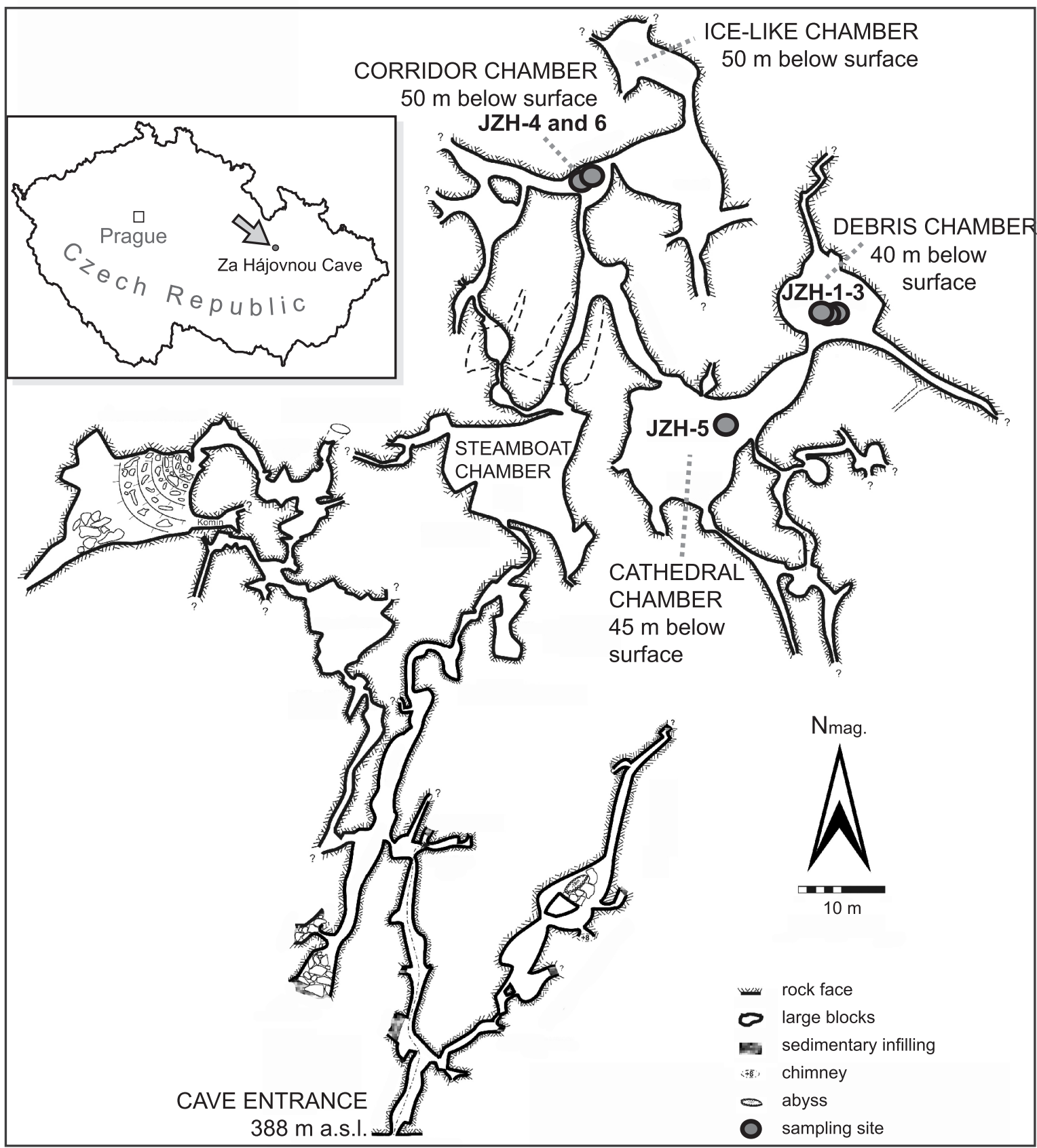

Fig. 1. Position of the Za Hájovnou Cave in the Czech Republic and a cave map with the locations of the CCC samples studied

Cave mapping and map drawing by A. Tomica and members of the Czech Speleological Society, Club 7-03 Javořičko; this map shows the known extent of the cave as of November 11, 2017; the vertical depth below the surface of the slope above the cave is shown for each sample of $\mathrm{CCC}_{\text {coarse }}$

Notably, the parts of the cave with $\mathrm{CCC}_{\text {coarse }}$ also display widespread damage of common speleothems. This damage was extensively discussed by Bábek et al. (2015). The most typical patterns of this damage are: cracked stalagmites and basal flowstones, stalagmites broken off near their bases, frequently shifted slightly laterally, though still standing on their bases (see e.g., Bábek et al., 2015: fig. 9A-C), broken and fallen thin stalactites, and fragments of speleothems attached by younger calcite precipitate to steep cave walls in positions where they could not have been fixed without the support of ma- terial formerly filling the cavity (Fig. 3). Our interpretation of these features is discussed below.

Sampling was focused only on $\mathrm{CCC}_{\text {coarse }}$ and similar types of speleothem consisting of loose particles. Samples of CCC were collected as grab samples, each containing at least several tens of crystals and their aggregates. A larger sample ( $\sim 50 \mathrm{~g} ; \mathrm{JZH}-1$; Figs. 2 and $4 \mathrm{~A}$ ) was collected for U-series dating and morphological and mineralogical studies from the Sut'ový Chamber, along with five smaller samples. The positions of sampling sites are shown in Figure 1. 


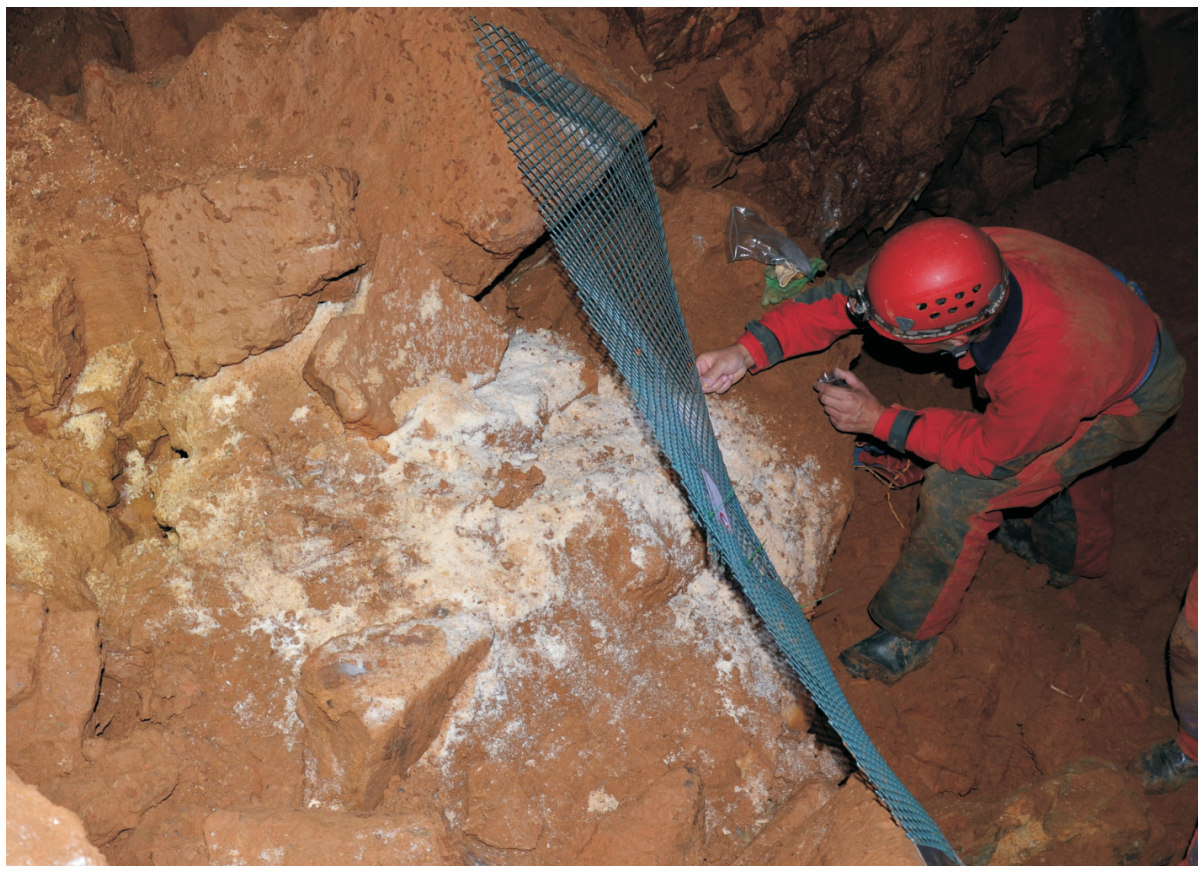

Fig. 2. A field photo of the occurrence of CCCcoarse in the Sut'ový (Debris) Chamber

The plastic net protects the site from pedestrian damage; the photo was taken from above, looking almost vertically downwards (photo by M. Orvošová)

\section{LABORATORY METHODS}

\section{MICROSCOPIC OBSERVATIONS}

The samples were studied using an OLYMPUS SZX16 stereo-microscope. QuickPHOTO Micro software and the Deep Focus module were used for photo documentation and image processing. The microscope was also used to clean the $\mathrm{CCC}_{\text {coarse }}$ samples of detritus for the dating. Since the dating method used requires $0.3 \mathrm{~g}$ of sample and since the size of the crystals and crystal aggregates dated was below this limit, a multi-grain sample was dated. For the $\mathrm{C}$ and $\mathrm{O}$ stable isotope analyses, three morphologically different sub-samples were separated from the $\mathrm{JZH}-1$ field sample. One subsample for $\mathrm{C}$ and $\mathrm{O}$ isotope analyses was separated from each of the other five field samples.

\section{U-Th DATING}

Chemical preparation was done at the U-series Laboratory of the Institute of Geological Sciences, Polish Academy of Sciences (Warsaw, Poland). The weight of the sample aliquot necessary for the separation procedure $(0.3 \mathrm{~g})$ required using several mineral grains and aggregates together. After thermal decomposition of organic matter, a ${ }^{233} U-{ }^{236} U-{ }^{229} \mathrm{Th}$ spike was added, the sample was dissolved in nitric acid, and uranium and thorium were separated from the solution using a chromatographic method with TRU-resin (a transuranium extraction chromatographic material in which the extractant system is octylphenyl- $\mathrm{N}, \mathrm{N}$-di-isobutyl carbamoylphosphine oxide dissol- ved in tri-n-butyl phosphate). Internal standard samples and blank samples were prepared simultaneously with the sample studied.

Isotopic ratios of $U$ and $T h$ of the prepared solutions were measured at the Institute of Geology of the Czech Academy of Sciences (Prague, Czech Republic). Measurements were performed with a double-focusing sector-field ICP mass analyser (Element 2, Thermo Finnigan MAT). The instrument was operated at a low mass resolution $(\mathrm{m} / \Delta \mathrm{m} \geq 300)$. Measurement results were corrected for counting background and chemical blank. Final results (Table 1 ) are reported as activity ratios. $\mathrm{U}$-series ages were iteratively calculated from the ${ }^{230} \mathrm{Th} /{ }^{234} \mathrm{U}$ and ${ }^{234} \mathrm{U} /{ }^{238} \mathrm{U}$ activity ratios using the decay constants of Cheng et al. (2000). All uncertainties were evaluated and taken into account when assessing age uncertainty using error propagation rules. Reported errors are 2 standard deviation values.

\section{CARBON AND OXYGEN ISOTOPE COMPOSITION OF THE SPELEOTHEMS}

Carbon and oxygen stable isotope composition was measured after decomposition with $100 \% \mathrm{H}_{3} \mathrm{PO}_{4}$ under vacuum at $25^{\circ} \mathrm{C}$. C and $\mathrm{O}$ isotope ratios of the prepared $\mathrm{CO}_{2}$ gas were measured against the laboratory working standard prepared simultaneously with the samples using a Delta V Advantage (Thermo Scientific) mass spectrometer (Laboratories of the Czech Geological Survey in Prague). All samples were of calcitic chemistry. The results were recalculated relative to the international V-PDB standard. Overall analytical uncertainty of $\delta^{13} \mathrm{C}$ and $\delta^{18} \mathrm{O}$ values was $\pm 0.1 \%$. 

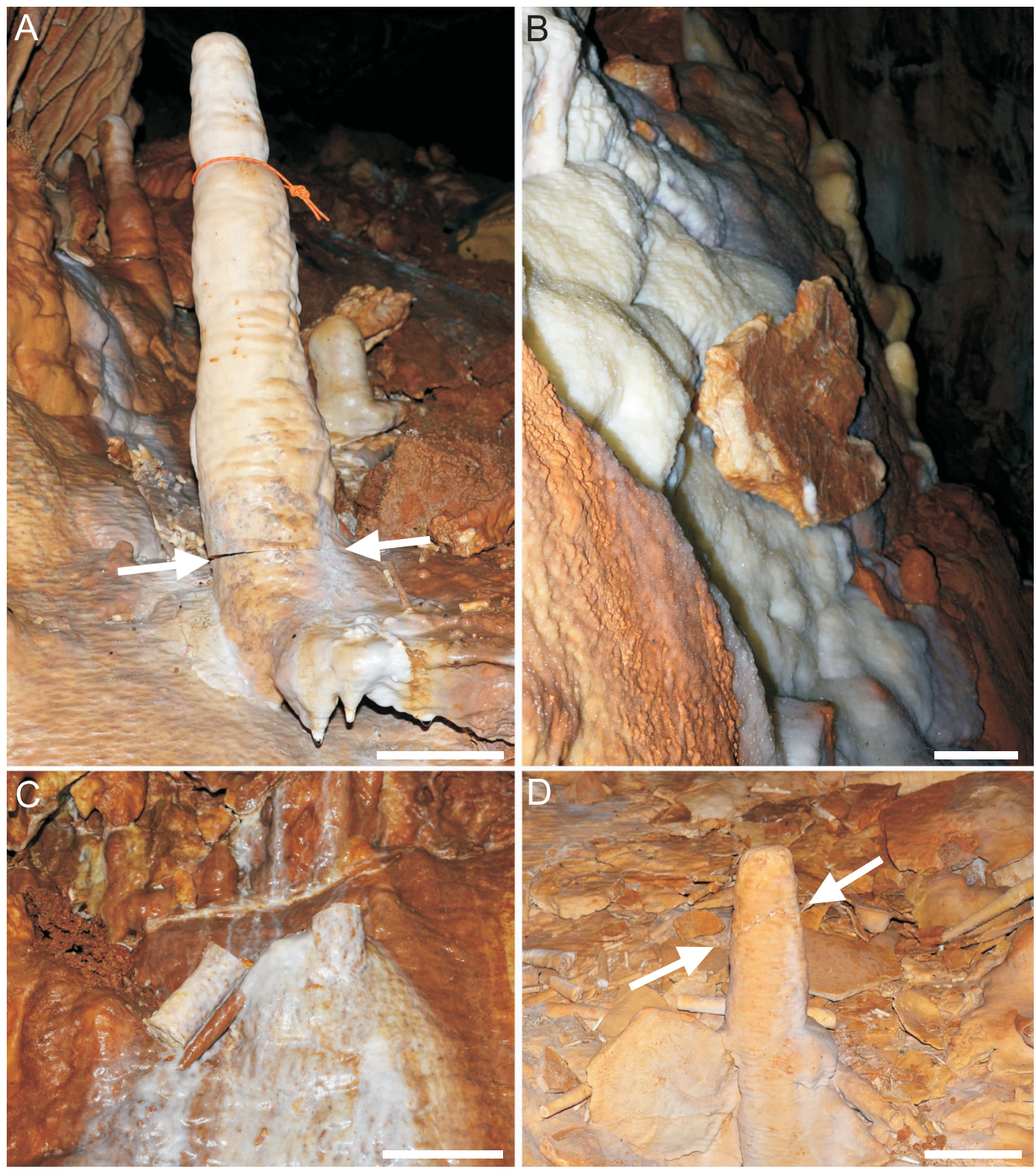

Fig. 3. Examples of speleothem damage interpreted as cryogenic

A - a stalagmite with a lateral open fracture (indicated by arrows) near its base standing in a vertical position, Steamboat Chamber, the red cord is to prevent touching of the unstable stalagmite; B, C - examples of so-called "ice attachments": B - a fragment of broken speleothem fixed in a position where it could not have been fixed without a support of some material (ice, in our interpretation) that had once filled the cavity, Katedrála (Cathedral) Chamber, eastern chamber wall, on a wall inclined at $70^{\circ}, \sim 5 \mathrm{~m}$ above the chamber bottom. $\mathrm{C}-$ another example of stalactite fragments calcite-cemented to a steep cave wall, Koridor (Corridor) Chamber; $\mathbf{D}$ - a standing stalagmite with its top broken along an inclined fracture (indicated by arrows), Steamboat Chamber. Scale bars represent $10 \mathrm{~cm}$ (photos by M. Orvošová)

\section{RESULTS}

The appearance of the collected carbonate material collected (sample JZH-1) corresponds well with typical loose accumulations of cryogenic origin ( Žák et al., 2018: figs. 6.4, 6.5 and 6.8). Sample JZH-1 consists of a mixture of two groups of different colours, both including various single crystals and their more or less complex intergrowths/aggregates (Fig. 4). The first group is represented especially by flat, elongated whitish crystals with serrated margins, which usually form fan- or tree-like aggregates (Fig. 5A). The second group is represented by pale buff-coloured crystals and aggregates, usually of (hemi)spherical, sheaf-like, chain-like (Fig. 5B1, B2) or planar raft-like appearance (Fig. 5B3, B4). Some aggregates consist of both the whitish and buff materials (Fig. 5B3, B4, C). Subsamples separated for the $\mathrm{C}$ and $\mathrm{O}$ isotope analyses (single aggregate or multiple aggregates homogenized together) represented the most common type of crystal.

The particles dated dominantly contained flat elongated whitish crystals with serrated margins, which usually form fanor tree-like aggregates (which can be easily identified in the 
overall photo of the sample JZH-1; Fig. 4). The sample had enough $U$ and low clastic thorium admixture (no correction for clastic Th was required). Precise dating was therefore possible (Table 1).

Crystals and crystal aggregates in all other (not dated) samples $\mathrm{JZH}-2$ to $\mathrm{JZH}-6$ also display characteristic morphologies pointing to their cryogenic origin and have the general appearance of material in sample $\mathrm{JZH}-1$. However, subtle variations could be observed at each site. Sample JZH-2 contains specific elongated crystals with triangular side faces (Fig. 6A), which are similar to the crystals described and discussed by Richter et al. (2018). Sample JZH-3 is typified by the abundance of more or less spherical to sheaf-like forms (Fig. 6B), whereas samples $\mathrm{JZH}-4$ and 5 are characterized by rather planar or even raft-like forms (Fig. 6C, D). Sample JZH-6 contains a significant portion of simple intergrowths of rhombohedral crystals (Fig. 6E). In addition, samples from sites JZH-5 and JZH-6 differ from the others in their etched surfaces (Fig. 6D, E), probably due to the action of aggressive drip water or due to the action of melting water derived from the former cavity ice infill.

Carbon and oxygen stable isotope values (Table 2) are in the range of data typical of $\mathrm{CCC}_{\text {coarse }}$ from Central European caves (Žák et al. 2004, 2012, 2018) with very low $\delta^{18} \mathrm{O}$ values down to $-22.65 \%$ V-PDB and with a typical negatively sloped trend of data in the $\delta^{13} \mathrm{C}$ vs. $\delta^{18} \mathrm{O}$ space (during the $\mathrm{CCC}_{\text {coarse }}$ crystallization, $\delta^{18} \mathrm{O}$ values of $\mathrm{CCC}_{\text {coarse }}$ decrease and $\delta^{13} \mathrm{C}$ values slightly increase; Žák et al., 2004).

\section{DISCUSSION}

\section{THE AGE AND ORIGIN OF THE SAMPLES STUDIED}

The age of $29.5 \pm 0.1 \mathrm{ka}$ BP obtained from the $\mathrm{CCC}_{\text {coarse }}$ site located in the Sut'ový Chamber corresponds to the Weichselian glacial, to the slightly warmer MIS 3, shortly before the beginning of the Last Glacial Maximum (MIS 2). During MIS 3, the permafrost produced during earlier MIS 4 was destroyed, with periods of permafrost melting from above being the most suitable for the formation of cryogenic carbonates in deep-located caves (Pielsticker, 2000). With respect to the known succession of morphological types formed during progressive precipitation of CCC $_{\text {coarse }}$ (Žák et al., 2018), we suppose that the mineral grains of similar morphology, selected for the U-series dating from a single site, represent a single event of karst water freezing. We consider the dating of one bulk sample sufficient to demonstrate freezing conditions in the cave at the time indicated. More detailed sampling at a higher number of sites and additional U-series dates are clearly needed to decide whether or not the precipitation of $\mathrm{CCC}_{\text {coarse }}$ in the cave occurred repeatedly at different time periods in the past. The cave most probably hosts also $\mathrm{CCC}_{\text {coarse }}$ sites produced during the destruction of the MIS 2 permafrost.

The locations of $\mathrm{CCC}_{\text {coarse }}$ sites in the cave, the crystal/aggregate morphology, the $\mathrm{C}$ and $\mathrm{O}$ isotope data, and the $\mathrm{U}$-Th date clearly point to the cryogenic origin of the carbonates stud-

Results of the U-series dating of sample JZH-1

\begin{tabular}{|c|c|c|c|c|c|c|}
\hline Lab.No. & Sample & conc. U [ppm] & ${ }^{234} \mathrm{U} /{ }^{238} \mathrm{U}$ & ${ }^{230} \mathrm{Th} /{ }^{234} \mathrm{U}$ & ${ }^{230} \mathrm{Th} /{ }^{232} \mathrm{Th}$ & Age $[\mathrm{ka}]$ \\
\hline 561 & Za Hájovnou & $0.7122 \pm 0.0007$ & $3.225 \pm 0.004$ & $0.244 \pm 0.0007$ & $144.5 \pm 0.5$ & $29.5 \pm 0.1$ \\
\hline
\end{tabular}

Results of the $\mathrm{C}$ and $\mathrm{O}$ stable isotope determinations on samples from the Za Hájovnou Cave

\begin{tabular}{|c|c|c|c|}
\hline $\begin{array}{l}\text { Sample } \\
\text { No. }\end{array}$ & Sample description & $\begin{array}{c}\delta^{13} \mathrm{C} \\
{[\%, \mathrm{~V}-\mathrm{PDB}]}\end{array}$ & {$\left[\%, \delta^{18} \mathrm{O}\right.$} \\
\hline $\mathrm{JZH}-1 / 1$ & $\begin{array}{c}\text { Sut'ový (Debris) Chamber; small, mainly skeletal forms, } \\
\text { equivalent to the type shown in Figure } 5 \mathrm{~A}\end{array}$ & -5.47 & -18.97 \\
\hline $\mathrm{JZH}-1 / 2$ & $\begin{array}{c}\text { Sut'ový (Debris) Chamber; a larger skeletal aggregate, } \\
\text { equivalent to the type shown in Figure } 5 \mathrm{~A}\end{array}$ & -6.38 & -16.69 \\
\hline $\mathrm{JZH}-1 / 3$ & $\begin{array}{c}\text { Sut'ový (Debris) Chamber; several larger globular forms, } \\
\text { equivalent to the type shown in Figure 5B1-B3 }\end{array}$ & -4.21 & -22.65 \\
\hline $\mathrm{JZH}-2$ & $\begin{array}{l}\text { Sut'ový (Debris) Chamber; sample from a small site on the slope about } 1 \mathrm{~m} \text { above } \\
\text { JZH-1, elongated crystals outside the main accumulation }\end{array}$ & -9.12 & -11.42 \\
\hline $\mathrm{JZH}-3$ & $\begin{array}{c}\text { Sut'ový (Debris) Chamber; second sampling from site JZH-1, a } 6 \text { mm large, } \\
\text { partly trihedral globular form }\end{array}$ & -4.60 & -19.87 \\
\hline $\mathrm{JZH}-4$ & $\begin{array}{c}\text { Koridor (Corridor) Chamber; small concretions from the clay sediment at the bottom, } \\
\text { outside the } \mathrm{CCC}_{\text {coarse }} \text { accumulations }\end{array}$ & -9.19 & -11.53 \\
\hline $\mathrm{JZH}-5$ & Katedrála (Cathedral) Chamber; a larger aggregate, corroded on the surface & -7.06 & -13.42 \\
\hline $\mathrm{JZH}-6$ & Koridor (Corridor) Chamber; a large aggregate of crystals & -6.20 & -15.42 \\
\hline
\end{tabular}




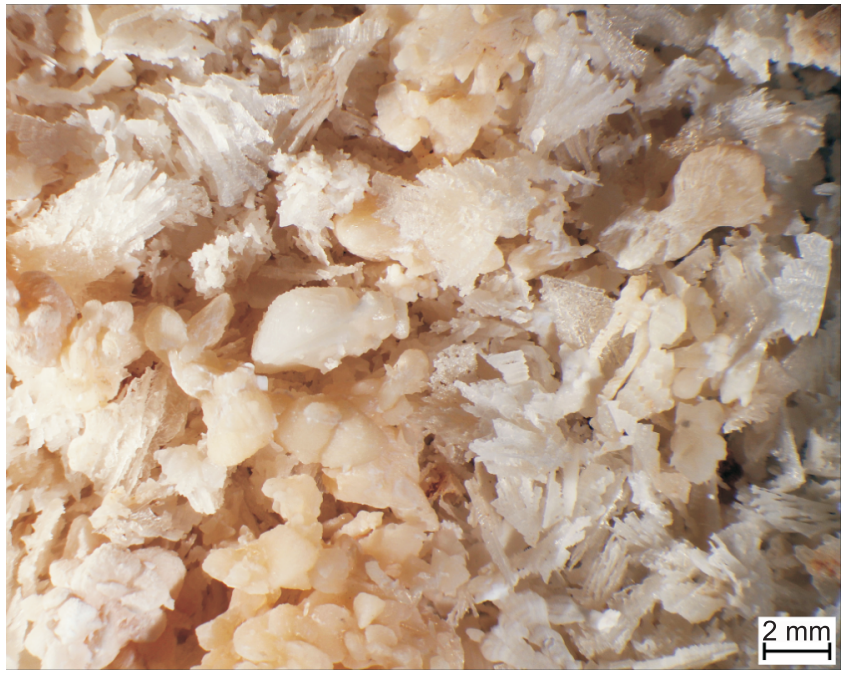

Fig. 4. A general view of the studied sample JZH-1, Su ový (Debris) Chamber

Photo by M. Filippi ied and therefore also to the existence of ice and freezing temperatures in the parts of the Za Hájovnou Cave studied (Fig. 1). Samples $\mathrm{JZH}-2$ and $\mathrm{JZH}-4$, representing loose speleothems (loose crystals and crystal aggregates) sampled outside the main cryogenic accumulations, have $\delta^{13} \mathrm{C}$ and $\delta^{18} \mathrm{O}$ data closer to the range of typical common speleothems (Table 2) and are probably either of non-cryogenic origin, or represent a very early stage of water pool freezing. The crystal habitus of sample $\mathrm{JZH}-2$ is very similar to that of crystals formed at the onset of freezing described in detail by Richter et al. (2018). Unequivocal identification of $\mathrm{CCC}_{\text {coarse }}$ in the field is difficult, since some other speleothem types can also produce accumulations of a loose character (e.g., cave rafts). Therefore, $\mathrm{C}$ and $\mathrm{O}$ isotope data (reaching extremely low $\delta^{18} \mathrm{O}$ values) are necessary to confirm the cryogenic origin.

\section{SPELEOTHEM DAMAGE AND FORMER ICE FILL OF THE CAVITIES}

Two major caves of the Javoříčko Karst, the Javořičko Cave and Za Hájovnou Cave, contain widespread manifestations of speleothem damage. The issue of speleothem damage is generally very complex. Our field experience suggests that speleothem damage in a single particular cave can be a result of several different processes, occurring repeatedly at different moments in the past. Any unequivocal conclusions based on a

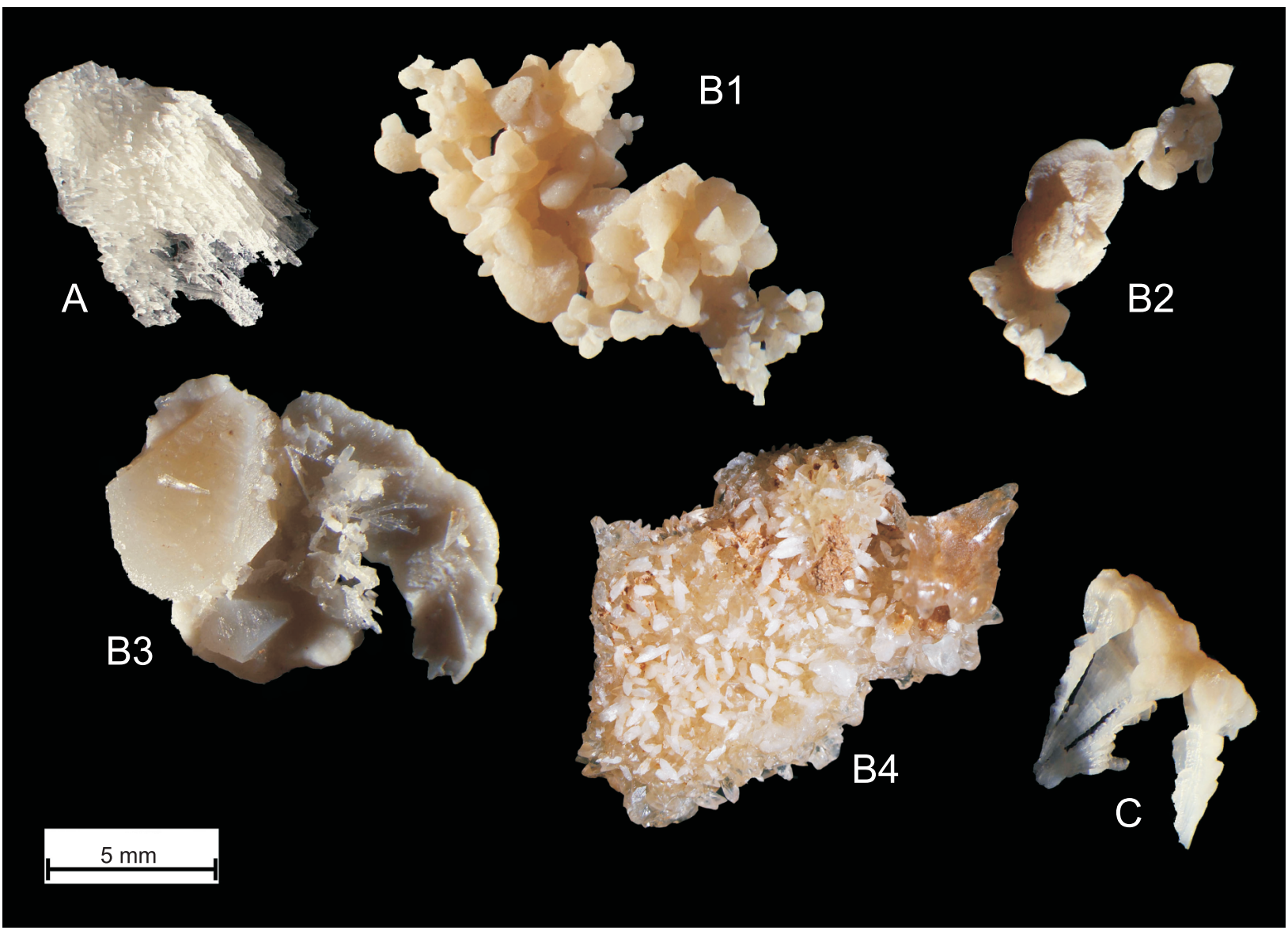

Fig. 5. Selected morphological types of $\mathrm{CCC}_{\text {coarse }}$ occurring in sample JZH-1 
brief field observation or a couple of analysed samples bring an incomplete understanding. Bábek et al. (2015) interpreted speleothem damage in the Za Hájovnou Cave (and in some other caves in a wider area) as being mainly a result of former tectonic movements and related seismic activity. The movements were presumed to have occurred on faults directly crosscutting the caves. The timing of these inferred fault movements, estimated from the U-Th dating of stalactite fractures (3 broken stalactites studied; Bábek et al., 2015), was reported as Pleistocene, with the last speleothem damage event dating to MIS 6 and MIS 5.

Bábek et al. (2015) also discussed the potential for the cryogenic origin of speleothem damage and concluded, based largely on the absence of any evidence for cryoturbation, that "we strongly incline towards a tectonic and not cryogenic origin". In this respect it is important to emphasize that cryoturbation is a process typical only of environments affected by seasonal climatic cycles and therefore by numerous freezing and thawing events. We suppose that caves located deeper in the permafrost were affected by a very low number of freezing and thawing cycles, and cryoturbation features therefore cannot develop in them. Within cave environments, cryoturbation features have been documented in wide-entrance ice caves affected by strong airflow, i.e., an environment with numerous seasonal freezing and thawing cycles (Žák et al., 2013). Surface cryoturbation features known in the high arctic or mountain permafrost areas also typically affect mainly the active permafrost layer with seasonal freeze-and-thaw cyclicity, not the whole permafrost thickness (French, 2007).

The dating of the stalactite fractures provided by Bábek et al. (2015) was, for practical reasons, performed at three sites where the fractures were overgrown by a younger speleothem generation. The youngest fractures without overgrowths cannot be dated this way. This fact decreases the reference value of the age provided. It is also important to note that the cave area where the supposed tectonic sediment disturbance was observed by Bábek et al. (2015) bears evidence of widespread relocation of clastic cave sediments into deeper cavities and related gravitational movements of the remaining sediment mass. The sediment movement observed has not been dated.

Generally, speleothem damage (except for intentional vandalism or non-intended damage by cave visitors) can result from many natural processes (e.g., Gilli, 2004; Kempe, 2004; Becker et al., 2006; Šebela, 2008; Filippi et al., 2011; Bábek et al., 2015, and other papers cited therein). These processes include, besides the influence of earthquakes and tectonic movements on cracks and faults, various "movements" of unconsolidated sediments: slope movements, compaction, desiccation, influence of erosion of unconsolidated sediments supporting the speleothems, speleothem falling due to rock collapses, etc. Typical processes causing speleothem damage also include corrosion of speleothems and their former connections to cave walls or roofs. The impact of animals (especially various vertebrates), stalactite falling because of overweighting by growth or speleothem damage by artificial blasting in adjacent quarries cannot be excluded. Unequivocal identification of any of these causes as a specific process resulting in the damage of a particular speleothem is therefore difficult. Cryogenic processes in caves, which include the breaking force of ice crystallization in the pores/fractures of speleothems or the mechanical action of moving bottom ice which once filled the cavity, have the advantage that several rare types of cryogenic damage are morphologically unique and can therefore be unequivocally distinguished. These features have been studied by several authors, especially in Central Europe, in a zone which falls within the periglacial realm of former Pleistocene glaciations (e.g., Kem- pe, 1989, 2008; Pielsticker, 1998, 2000; Wrede, 1999; Kempe and Rosendahl, 2003; Kempe and Henschel, 2004; Kempe et al., 2006; Orvošová et al., 2012). Speleothem damage by ice pressure was advocated even for some quite southerly caves such as Postojnska Jama, Slovenia (Kempe, 2004; Kempe and Henschel, 2004), although this interpretation was later considered unlikely by Šebela (2008).

One of the common types of stalagmite damage in the $\mathrm{Za}$ Hájovnou Cave is represented by laterally fractured thick and short stalagmites. The tops of these stalactites are shifted a few $\mathrm{mm}$ or $\mathrm{cm}$ laterally but still stay on their bases (Bábek et al., 2015: fig. 9A-C; Fig. 3A, D in this paper). Should the seismic event be of sufficient intensity to laterally fracture relatively short and thick massive stalagmites, the broken part would certainly fall down and would not stay in place with an open fracture on its base (cf. Kagan et al., 2005: fig. 1A and Fig. 3A, D in this paper). We consider these broken but standing massive stalagmites as a typical example of side pressure of the cavity ice fill (cf. Gilli, 1999, 2004; Lacave et al., 2004; Becker et al., 2006).

Probably the best evidence of the former ice fill of the cavity is represented by fragments of speleothems, which are fixed at positions where they cannot be deposited by simple falling. Typical examples are fragments attached (calcite-cemented) to steep or vertical sections of cave walls where they could never be fixed without the support of ice (or some other type of sediment once filling the cavity). These features have been studied thoroughly in Germany (Kempe, 1989, 2008; Pielsticker, 1998, 2000; Wrede, 1999; Kempe and Rosendahl, 2003; Kempe and Henschel, 2004; Kempe et al., 2006) where multiple evidence of former ice fill of the cavity was documented. In this manuscript, we term these specific morphological features "ice-supported attachments" (Fig. 3B, C). The positions of some of these ice-supported attachments, several metres above the cave chamber bottoms in the Za Hájovnou Cave, indicate that the thickness of the ice fill reached several metres. There is no indication of the former presence of some other kind of sediment (such as clay) cavity fill reaching up to the level where the attachments were documented. The underlying flowstone layers on the walls consist of pure calcite with no obvious clay contamination. It is characteristic that the cave locations containing ice-supported attachments usually contain also accumulations of $\mathrm{CCC}_{\text {coarse. }}$ It should be noted that the ice-supported attachments most probably represent a different phase of the cave ice fill growth and retreat than $\mathrm{CCC}_{\text {coarse }}$. While the $\mathrm{CCC}_{\text {coarse }}$ form during the freezing of cave pools, the ice-supported attachments probably formed later, during the ice fill melting. This is an aspect clearly requiring further study.

Ice filling the caves usually moves at much less velocities than it is typical for surface glaciers, given the limited space of the host cavities (Perşoiu, 2018b). This is indicated also by the fact that ice in caves located in permafrost is cold-based ice, without any melting near its base. Nevertheless, when the cave bottom is inclined, the flowing ice mass creates a side pressure on stalagmites standing on the bottom since the earlier warmer periods. This side force frequently results in breaking-off (cutting-off) of whole stalagmites or their parts by a single crack.

The evolution of ice fill in caves without wide open entrances is typically tightly related to evolution and destruction (thawing) of the permafrost. The behaviour of cave spaces during the evolution and destruction of permafrost is as yet poorly understood. However, it is generally accepted that permafrost aggradation (penetrating downwards from the surface) will gradually block the infiltration paths by ice, and water infiltration into caves becomes ineffective. Rather than being filled with ice, it is therefore likely that many cave spaces stayed empty during the permafrost thickness increase. As has been shown 


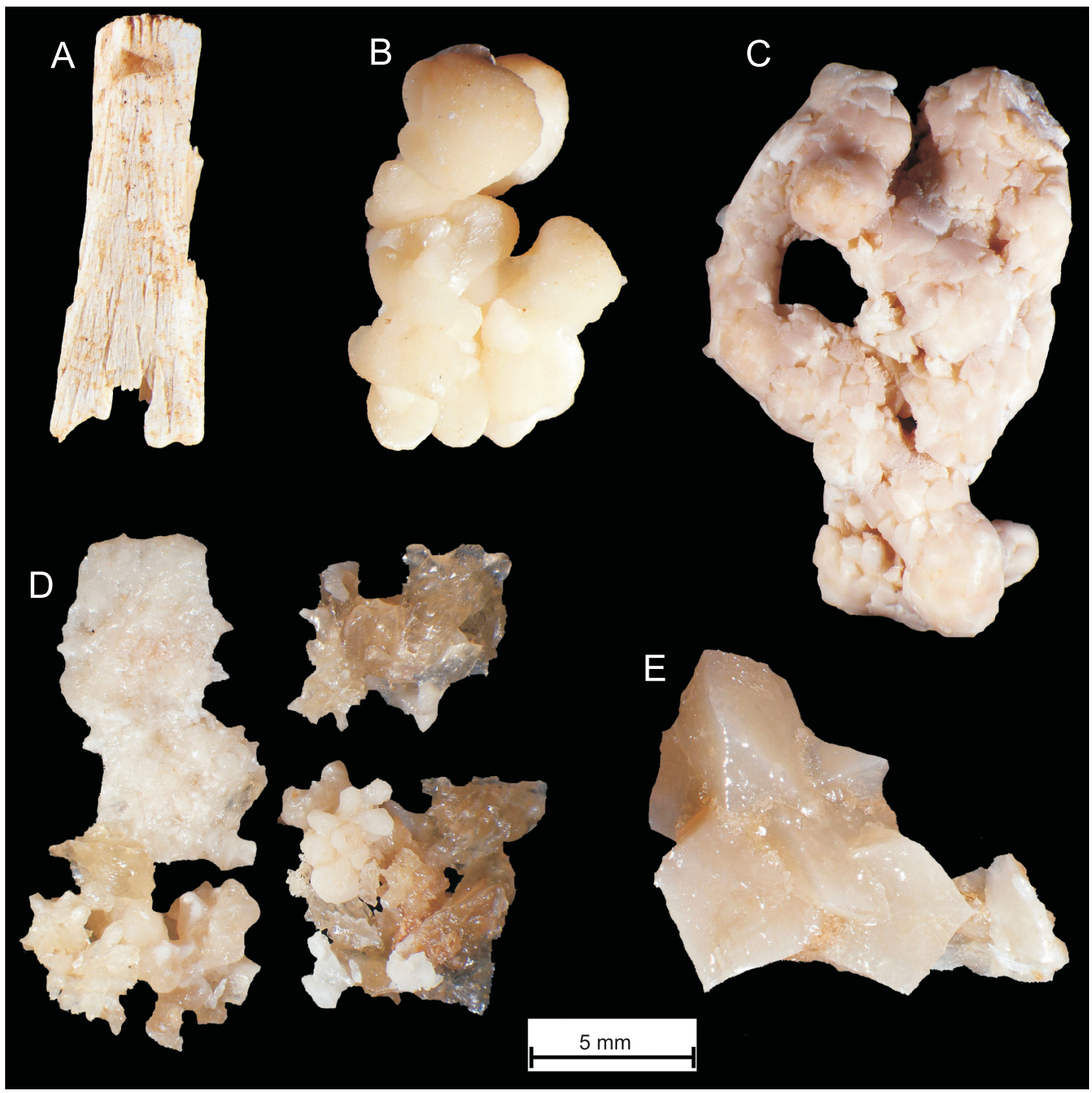

Fig. 6. Selected morphological types of $\mathrm{CCC}_{\text {coarse }}$ occurring in samples $\mathrm{JZH}-2$ to $\mathrm{JZH}-6$

See text for further explanation (photo by M. Filippi)

by Pielsticker (2000), the ice fill in a cavity located originally in permafrost was relatively short-lived and only occurred after the beginning of warmer periods. Empty cave spaces located in the relic permafrost zone and cooled to sub-zero temperature during the previous cold period are (usually partly) filled with water penetrating into them through water-conducing zones, along which the $0^{\circ} \mathrm{C}$ isotherm penetrates to the depth more quickly. Liquid water penetrating into still-frozen cavities becomes slowly frozen, which can result both in speleothem damage, and in the formation of cryogenic carbonates. As the $0^{\circ} \mathrm{C}$ isotherm moves deeper during further warming, the ice melts again.

Evidence of the relationship between the caves and tectonic zones is generally widespread and is given by the fact that the inception of karst conduits frequently follows these disturbed zones (as shown by Bábek et al., 2015, for the Za Hájovnou Cave). With respect to later movement on these zones, one feature has not been addressed in the published papers and we introduce it here. The dimensions of large rock segments change as a result of thermal expansion or contraction during the transitions from colder to warmer and warmer to colder surface climates. With respect to the fact that surface climatic changes penetrate into the underground with a delay, there is a tension generated and the volume/length changes can be compensated by a minor movement along pre-existing cracks and faults. Since the stalactites commonly grow directly on these cracks (which are water-conducting paths), stalactite falls can be also related to these minor climate-driven movements. Unfortunately, direct detailed studies on ongoing speleothem damage in recently glaciated caves are missing (usually only the result, i.e., damaged speleothems, is described, not the process; cf. theoretical considerations of Lundberg and McFarlane, 2012).

The conclusion of Bábek et al. (2015) about fault movement and seismic events causing a part of the speleothem damage in the Za Hájovnou Cave may be valid. Nevertheless, great care has to be taken in using broken speleothems as indicators of former endogenic tectonic activity (see detailed discussions in 
Gilli, 1999, 2004; Becker et al., 2006). It is only in relatively rare cases (e.g., Gilli et al., 1999; Kagan et al., 2005; Plan et al., 2010) that tectonic activity can be unequivocally identified as the cause of speleothem damage. Indeed, many direct observations made by cavers present in caves during strong earthquakes indicate little or no speleothem damage (Becker et al., 2006; the paper reports also some well-documented cases of tectonic/seismic damage), and most reports indicate that seismic damage typically affects only thin and long stalagmites and stalactites. The long and thin soda straw stalactites, which are in fact a fragile pendulum, are the most sensitive (Gilli et al., 1999). It is worth mentioning here that one of the authors (M.F.) visited Qeshm Island (southern Iran) a few days after a relatively strong earthquake (5.9 on the Richter magnitude scale) in 2005; although three villages were destroyed, no visible changes were observed in adjacent salt caves, which are richly decorated by various types of salt speleothems (Filippi et al., 2011).

\section{PERMAFROST THICKNESS IN THE AREA OF THE ZA HÁJOVNOU CAVE}

The presence of $\mathrm{CCC}_{\text {coarse }}$ in the Za Hájovnou Cave, the cryogenic origin of which we consider as proven, indicates freezing conditions in cavities located down to $50 \mathrm{~m}$ below the closest land surface. The cave morphology and almost complete blocking of the entrance corridors by clastic sediments before their artificial excavation indicate that cooling of the cavities by cave airflow was not possible during the Last Glacial. The existence of permafrost reaching down to $\sim 50 \mathrm{~m}$ can be viewed as the only reasonable explanation.

Another find of $\mathrm{CCC}_{\text {coarse }}$ in the adjacent Javořičko Cave (dated to a range of 38.1-34.6 ka; Žák et al., 2012) comes from a depth of $\sim 30 \mathrm{~m}$ below the surface. It is also accompanied in this cave by similar features of speleothem damage (especially in the Olomouc Chamber), strengthening the evidence that Weichselian permafrost existed in the Javoríčko Karst during MIS 4 and MIS 3 (and certainly also during MIS 2, for which evidence based on $\mathrm{CCC}_{\text {corse }}$ remains to be found).

If the documented permafrost thickness during MIS 4 and MIS 3 is compared with the following more severe Last Permafrost Maximum (during MIS 2; 25 to 17 ka BP; Vandenberghe et al., 2014), it may have reached even higher values during MIS 2. The study area lies within the permafrost zone on the maps of Vandenberghe et al. (2014) for this period. Czudek (2005: p. 49-53) estimated the thickness of permafrost during the Last Glacial Maximum at $>50 \mathrm{~m}$, exceptionally $250 \mathrm{~m}$, in the eastern part of the Czech Republic. The frequently cited paper of Růžičková and Zeman (1992) interpreted sedimentary structures in the Blahutovice borehole in northern Moravia to be cryogenic in origin down to a depth of $220 \mathrm{~m}$ below the surface. In NE Poland, $\sim 700 \mathrm{~km}$ to the NE of the study area, currently surviving relic permafrost was indicated at a depth of $357 \mathrm{~m}$; its maximum palaeothickness at the end of the Last Glacial Maximum was probably $\sim 600 \mathrm{~m}$ (Szewczyk, 2017). This example is given here not as an equivalent of permafrost depth in the study area, but as clear evidence of the long persistence of relic permafrost at depth.

Neither $\mathrm{CCC}_{\text {coarse }}$ nor cryogenic speleothem damage have been reported from extensive cave systems of the Moravian Karst, located at a similar altitude $\sim 35 \mathrm{~km}$ south of the study area. This absence can be explained either by abundant active subsurface water streams in the caves of Moravian Karst, importing heat into the underground during summer seasons (Ford and Williams, 2007: p. 421-427), or by location of the boundary between the widespread and sporadic permafrost zone during the second half of the Weichselian in the middle of Moravia.

\section{CONCLUSIONS}

Cryogenic phenomena such as cryogenic cave carbonates $\left(\mathrm{CCC}_{\text {coarse }}\right)$, ice-supported attachments, and characteristic cryogenic speleothem damage have been newly documented in the Za Hájovnou Cave. The U-series age of a sample collected from one of the richest $\mathrm{CCC}_{\text {coarse }}$ sites is $29.5 \pm 0.1 \mathrm{ka} \mathrm{BP}$, which corresponds to the end of MIS 3 within the Weichselian glacial. The abundance of cryogenic phenomena shows that the permafrost was present in this part of central Moravia, reaching a depth of at least $50 \mathrm{~m}$ below the surface (and probably deeper during the Last Glacial Maximum). The complexity of the cryogenic features indicates the presence of a former ice fill and suggests that cryogenic processes were an important cause of speleothem damage in the cave studied. However, distinguishing and evaluation of all possible processes causing speleothem damage in this cave, much like detailed understanding of particular stages of the permafrost aggradation and destruction, call for more detailed sampling and analytical work.

Acknowledgements. The research was conducted within institutional support No. RVO 67985831 of The Czech Academy of Sciences, Institute of Geology. U-series dating was financed through the bilateral mobility cooperation PAN 17-22 support to the Institute of Geology of the Czech Academy of Sciences and Institute of Geological Sciences of the Polish Academy of Sciences. Comments by the journal reviewer M. Gradziński, two anonymous reviewers and the Co-Editor T.M. Peryt significantly improved the manuscript and are highly appreciated.

\section{REFERENCES}

Bábek, O., Bristenský, M., Přecechtělová, G., Štěpančíková, P., Hellstrom, J.C., Drysdale, R.N., 2015. Pleistocene speleothem fracturing in the foreland of Western Carpathians: a case study from the seismically active eastern margin of the Bohemian Massif. Geological Quarterly, 59 (3): 491-506.

Becker, A., Davenport, C., Eichenberger, U., Gilli, E., Jeannin, P.Y., Lacave, C., 2006. Speleoseismology: a critical perspective. Journal of Seismology, 10: 371-388.

Colucci, R.R., Luetscher, M., Forte, E., Guglielmin, M., Lenaz, D., Princivalle, F., Vita, F., 2017. First alpine evidence of in situ coarse cryogenic cave carbonates $\left(\mathrm{CCC}_{\text {coarse }}\right)$. Geografia Fisica e Dinamica Quaternaria, 40: 53-59.

Cheng, H., Edwards, R.L., Hoff, J., Gallup, C.D., Richards, D.A., Asmerom, Y., 2000. The half-lives of uranium-234 and thorium-230. Chemical Geology, 169: 17-33.

Czudek, T., 2005. Quaternary Development of Landscape Relief in the Czech Republic (in Czech with English summary). Moravian Museum, Brno.

Filippi, M., Bruthans, J., Palatinus, L., Zare, M., Asadi, N., 2011 Secondary halite deposits in the Iranian salt karst: general de- 
scription and origin. International Journal of Speleology, 40: $141-162$.

Ford, D., Williams, P., 2007. Karst Hydrogeology and Geomorphology. J. Wiley and Sons, Chichester.

French, H.M., 2007. The Periglacial Environment. J. Wiley and Sons, Chichester.

Gilli, E., 1999. Rupture de spéléothèmes par fluage d'un remplissage endokarstique. L'exemple de la grotte de Ribière (Bouches-du-Rhône). Comptes Rendus de l'Académie des Sciences Paris, Series IIA, Earth and Planetary Science, 329: 807-813.

Gilli, E., 2004. Glacial causes of damage and difficulties to use speleothems as palaeoseismic indicators. Geodinamica Acta, 17: $229-240$.

Gilli, E., Levret, A., Sollogoub, P., Delange, P., 1999. Research on the February 18, 1996, earthquake in the caves of the SaintPaul-de-Fenouillet area (eastern Pyrenees, France). Geodinamica Acta, 12: 143-158.

Kadlec, J., Chadima, M., Pruner, P., Schnabl, P., 2005. Paleomagnetic dating of sediments in the "Za Hájovnou" Cave Javoříčko Karst, Moravia - preliminary results (in Czech). Př́rodovědné studie Muzea Prostějovska, 8: 75-82.

Kagan, E.J., Agnon, A., Bar-Matthews, M., Ayalon, A., 2005. Dating large infrequent earthquakes by damaged cave deposits. Geology, 33: 261-264

Kempe, S., 1989. Sinterschäden verursacht durch Permafrost oder Erdbeben? Mitteilungen des Verbandes der deutschen Höhlenund Karstforscher e.V. München, 35: 87-90.

Kempe, S., 2004. Natural speleothem damage in Postojnska Jama (Slovenia), caused by glacial cave ice? Acta Carsologica, 33: 265-289.

Kempe, S., 2008. Natürliche Sinterschäden, Indikatoren für glaziales Höhleneis in Mitteleuropa. Stalactite, 58: 39-42.

Kempe, S., Henschel, H-V., 2004. Alois Schaffenraths "zerbrochene Pyramide" (Postojnska Jama), ein Zeuge glazialer Höhlenvereisung? Mitteilungen des Verbandes der deutschen Höhlen- und Karstforscher e.V. München, 50: 76-81.

Kempe, S., Rosendahl, W., 2003. Speleothem damage in Central European Caves, a result of permafrost processes? Proceedings "Climate Changes: the Karst Record III", 3rd International Conference, Montpellier, France, 11th-14th May 2003, 88-89.

Kempe, S., Doeppes, D., Bauer, I., Dirks, H., Dorsten, I., Hueser, A., Eisenhauer, A., 2006. Naturally damaged speleothems, indicators of glacial cave ice in Central Europe. Karst Waters Institute Special Publication, 10: 35.

Kunský, J., 1939. Some forms of ice speleothems (in Czech). Rozpravy II. Třídy České Akademie, 49: 1-8.

Lacave, C., Koller, M.G., Egozcue, J.J., 2004. What can be concluded about seismic history from broken and unbroken speleothems? Journal of Earthquake Engineering, 8: 431-455.

Luetscher, M., Borreguero, M., Moseley, G.E., Spötl, C., Edwards, R.L., 2013. Alpine permafrost thawing during the Medieval Warm Period identified from cryogenic cave carbonates. Cryosphere, 7: 1073-1081

Lundberg, J., McFarlane, D.A., 2012. Cryogenic fracturing of calcite flowstone in caves: theoretical considerations and field observations in Kents Cavern, Devon, UK. International Journal of Speleology, 41: 307-316.

Lundberg, J., Musil, R., Sabol, M., 2014. Sedimentary history of Za Hájovnou Cave (Moravia, Czech Republic): a unique Middle Pleistocene palaeontological site. Quaternary International, 339-340: 11-24.

Musil, R., 2005. "Za Hájovnou" Cave, unique locality of the Javoříčko Karst (in Czech). Prírodovědné Studie Muzea Prostějovska, 8: 9-41.

Orvošová, M., Vlček, L., Holúbek, P., Orvoš, P., 2012. Frost and cave ice action as a cause of speleothem destruction during glacial: examples from selected caves in Slovakia. Slovenský Kras, Acta Carsologica Slovaca, 50: 157-172.

Perşoiu, A., 2018a. Ice caves climate. In: Ice Caves (eds. A. Perşoiu and S.-E. Lauritzen): 21-32. Elsevier.

Perşoiu, A., 2018b. Ice dynamics in caves. In: Ice Caves (eds. A. Perşoiu and S.-E. Lauritzen): 97-108. Elsevier.
Pielsticker, K.-H., 1998. Die Große Sunderner Höhle, Sundern, Hochsauerlandkreis, BRD. Sinterbrüche und Umlagerungen, Eisdruck oder Erdbeben. Mitteilungen des Verbandes der deutschen Höhlen- und Karstforscher e.V. München, 44: 4-11.

Pielsticker, K.-H., 2000. Höhlen und Permafrost - Thermophysikalische Prozesse von Höhlenvereisungen während des Quartärs. Bochumer geologische und geotechnische Arbeiten, 55: 187-196.

Plan, L., Grasemann, B., Spötl, C., Decker, K., Boch, R., Kramers, J., 2010. Neotectonic extrusion of the Eastern Alps: Constraints from the U/Th dating of tectonically damaged speleothems. Geology, 38: 483-486.

Richter, D.K., Riechelmann, D.F.C., 2008. Late Pleistocene cryogenic calcite spherolites from the Malachitdom Cave (NE Rhenish Slate Mountains, Germany): origin, unusual internal structure and stable $\mathrm{C}-\mathrm{O}$ isotope composition. International Journal of Speleology, 37: 119-129.

Richter, D.K., Neuser, R.D., Harder, M., Schabdach, H., Scholz, D., 2018. Unusual internal structure of $\mathrm{cm}$-sized coldwater calcite: Weichselian spars in former pools of the Zinnbergschacht Cave (Franconian Alb/SE Germany). International Journal of Speleology, 47: 145-154

Růžičková, E., Zeman, A., 1992. The Blahutovice-1 borehole near Hranice na Moravě: weathering effects in Badenian deposits. Scripta, Geological Series, Masaryk University, 22: 128-132.

Šebela, S., 2008. Broken speleothems as indicators of tectonic movements. Acta Carsologica, 37: 51-62.

Spötl, C., Cheng, H., 2014. Holocene climate change, permafrost and cryogenic carbonate formation: insights from a recently deglaciated, high-elevation cave in the Austrian Alps. Climate of the Past, 10: 1349-1362.

Szewczyk, J., 2017. The deep-seated lowland relic permafrost from the Suwałki region (NE Poland) - analysis of conditions of its development and preservation. Geological Quarterly, 61 (4): 845-858.

Vandenberghe, J., French, H.M., Gorbunov, A., Marchenko, S., Velichko, A.A., Jin, H., Cui, Z., Zhang, T., Wan, X., 2014. The Last Permafrost Maximum (LPM) map of the Northern Hemisphere: permafrost extent and mean annual air temperatures, 25-17 ka BP. Boreas, 43: 652-666.

Vaněk, M., 2012. New discoveries in the Za Hájovnou Cave in Javoříčko, Javoříčko Karst, Central Moravia (in Czech). Speleofórum, 31: 58-61.

Vaněk, M., Kučera, J., 2018. Za Hájovnou Cave at Javoříčko Karst - one kilometre is just a beginning (in Czech). Speleofórum, 37: 36-38.

Van Meerbeeck, C.J., Renssen, H., Roche, D.M., 2009. How did Marine Isotope Stage 3 and Last Glacial Maximum climates differ? - perspectives from equilibrium simulations. Climate of the Past, 5: 33-51.

Wrede, V., 1999. Sinterschäden in der Großen Sunderner Höhle ein Beweis für Eisdruck? Mitteilungen des Verbandes der deutschen Höhlen- und Karstforscher e.V. München, 45: 12-14.

Žák, K., Urban, J., Cílek, V., Hercman, H., 2004. Cryogenic cave calcite from several Central European caves: age, carbon and oxygen isotopes and a genetic model. Chemical Geology, 206: 119-136.

Žák, K., Onac, B.P., Perşoiu, A., 2008. Cryogenic carbonates in cave environments: A review. Quaternary International, 187: 84-96.

Žák, K., Richter, D.K., Filippi, M., Živor, R., Deininger, M., Mangini, A., Scholz, D., 2012. Coarsely crystalline cryogenic cave carbonate - a new archive to estimate the Last Glacial minimum permafrost depth in Central Europe. Climate of the Past, 8: $1821-1837$

Žák, K., Orvošová, M., Filippi, M., Vlček, L., Onac, B.P., Perşoiu, A., Rohovec, J., Světlík, I., 2013. Cryogenic cave pearls in the periglacial zone of ice caves. Journal of Sedimentary Research, 83: $207-220$.

Žák, K., Onac, B.P., Kadebskaya, O., Filippi, M., Dublyansky, Y., Luetscher, M., 2018. Cryogenic mineral formation in caves. In: Ice Caves (eds. A. Perşoiu and S.-E. Lauritzen): 123-162. Elsevier. 